\title{
Homogenous Particleboard Made from Whole Cotton (Gossypium hirsutum L.) Stalk Agricultural Waste: Optimisation of Particle Size and Influence of Cotton Residue on Performance
}

\author{
Thanh Tung Nguyen, ${ }^{\mathrm{a}, \mathrm{c}, *}$ Henri Bailleres, ${ }^{\mathrm{d}}$ Adam Redman, ${ }^{\mathrm{d}}$ William Leggate, ${ }^{\mathrm{d}}$ \\ Luigi-j Vandi, ${ }^{\text {b,c }}$ and Michael Heiztmann ${ }^{\text {a,c, } *}$
}

\begin{abstract}
The objective of this research was to characterize the cotton stalk resource. This paper also focused on the manufacturing of formaldehydefree particleboards using whole cotton stalk. The effects of opening particle sizes and cotton ball residue ratios on performance properties of manufactured particleboard was assessed. Modulus of rupture (MOR), modulus of elasticity (MOE), internal bond (IB), and thickness swelling (TS) were characterized. Particleboards manufactured from four different opening particle sizes $(6,8,10$, and $20 \mathrm{~mm})$ using an emulsifiable polymeric isocyanate adhesive (eMDI) were investigated. Similarly, the same performance properties were evaluated using four different cotton ball residue ratios $(0,5,10$, and $15 \mathrm{wt} \%)$. Results showed that the stem length and diameter of cotton stalks cultivated in Queensland (Australia) vary greatly and range from 160 to $890 \mathrm{~mm}$ and 5.03 to $10.88 \mathrm{~mm}$, respectively. The highest weight proportion of the resource is the cotton stem making up $46 \mathrm{wt} \%$ of the available resource. The highest average values of MOR, MOE, IB, and the lowest TS were observed for boards with an opening particle size of $8 \mathrm{~mm}$. The cotton ball residues had detrimental effects on the mechanical properties with a decrease in properties observed with increasing cotton ball residue load.
\end{abstract}

Keywords: Cotton stalks; Emusifiable polymeric isocyanate (eMDI) adhesive; Particleboard

Contact information: a: School of Mechanical and Mining Engineering, The University of Queensland, Brisbane, QLD 4072, Australia; b: School of Chemical Engineering, The University of Queensland, Brisbane, QLD 4072, Australia; c: Centre for Advanced Materials Processing and Manufacturing, The University of Queensland, Brisbane, QLD 4072, Australia; d: Queensland Department of Agriculture and Fisheries, Horticulture and Forestry Science, Salisbury Research Facility, 50 Evans Rd, Salisbury, QLD 4107, Australia; *Corresponding authors: thanhtung.nguyen@uq.edu.au; m.heitzmann@uq.edu.au

\section{INTRODUCTION}

The global demand for wood and wood-based panels has considerably increased in recent decades and it is projected to continue to grow. According to the Food and Agriculture Organization of the United Nations' (FAO) yearbook of forest and forest products (FAO 1997, 2002, 2007, 2012, and 2017), the world consumption of wood-based panels was 139 million cubic meters in 1995 and has grown to 393.2 million cubic meters by 2015. The global consumption of particleboards increased from 60.9 million cubic meters to 110 million cubic meters for the same period. Furthermore, the international average annual growth rate of sawn wood consumption for the period of 2020 to 2030 is predicted to be approximately $1.4 \%$, and the figure for wood-based panels is estimated at $2.9 \%$ (FAO 2009). This leads to high pressures on diminishing forest resources. Therefore, 
research into alternative fiber resources for the manufacturing of wood-based panels in general and particleboards in particular has gained popularity. Agricultural waste, such as rice straw, rice husk, sorghum stalks, and cotton stalks, have been considered as a potential lignocellulosic material source for particleboard production. The development of particleboards based on agricultural waste presents a significant opportunity, particularly for regions without access to sustainable timber resources. Utilizing these alternative resources not only reduces pressure on forest resources but also helps in minimizing environmental impacts by preventing incineration as a mode of reducing trash between crop rotations. For the particleboard production, a particularly promising source is cotton stalk. As shown in Table 1, cotton stalks have similar hemicellulose and cellulose content to the most common hardwood species commonly used in the particleboard industry.

Table 1. Chemical Composition of Cotton Stalks and Hardwood Species

\begin{tabular}{|c|c|c|c|c|c|c|}
\hline \multirow[b]{2}{*}{$\begin{array}{l}\text { Type of } \\
\text { Materials }\end{array}$} & \multicolumn{5}{|c|}{ Chemical Composition Components } & \multirow[b]{2}{*}{ Reference } \\
\hline & $\begin{array}{l}\text { Hemicellulose } \\
(\%)\end{array}$ & $\begin{array}{l}\text { Cellulose } \\
(\%)\end{array}$ & $\begin{array}{l}\text { Lignin } \\
(\%)\end{array}$ & $\begin{array}{l}\text { Ash } \\
(\%)\end{array}$ & $\begin{array}{c}\text { Silica } \\
(\%)\end{array}$ & \\
\hline \multirow{3}{*}{$\begin{array}{l}\text { Cotton } \\
\text { Stalk }\end{array}$} & 30.1 & 45.5 & 18.2 & 2.52 & 0.48 & Tutus et al. 2010 \\
\hline & 29.7 & 47.8 & 21.2 & 1.3 & - & Ertaş et al. 2010 \\
\hline & 28.96 & 42.5 & 20.5 & 5.54 & - & Soulama et al. 2015 \\
\hline Rice Straw & 35.5 & 39.63 & 13.92 & 12.51 & 9.68 & $\begin{array}{l}\text { El-Kassas and } \\
\text { Mourad } 2013\end{array}$ \\
\hline $\begin{array}{l}\text { Sorghum } \\
\text { Stalk }\end{array}$ & 33.95 & 34.87 & 23.02 & 4.2 & - & Kusumah et al. 2016 \\
\hline $\begin{array}{l}\text { Hardwood } \\
\text { Species }\end{array}$ & 25 to 28 & 45 to 50 & $\begin{array}{c}30 \text { to } \\
35\end{array}$ & 0.35 & - & $\begin{array}{c}\text { Pirayesh and } \\
\text { Khazaeian } 2012 \\
\end{array}$ \\
\hline
\end{tabular}

In Australia, cotton (Gossypium hirsutum L.) is cultivated only in Queensland and New South Wales with the five-year average (2011 to 2016) being 372,000 hectares (ABARES 2017). One hectare of cotton generates roughly three tons of dry stalks (Gomes et al. 1997). This indicates that approximately 1.2 million tons of cotton stalks are annually produced in Australia. At present, almost all of this waste is either burnt in the field leading to air pollution (Zhou et al. 2010; Kargarfard and Latibari 2011) and a decrease in soil biological activity (Alma et al. 2005) or plowed into the soil, which provides an ideal living place for pests during winter (Seedahmed 2014). Therefore, burning cotton stalk waste or incorporating this waste into the soil wastes a potentially underutilized resource.

A small number of studies on the utilization of cotton stalks for the manufacture of particleboards have been conducted. Particleboards made from cotton stalks without bark and other impurities, using urea formaldehyde resin were investigated by Guler and Ozen (2004). Their results showed that cotton stalks are a valuable raw material and that this resource can be used as alternative material for particleboard production. An investigation on the properties of cotton carpel-based particleboards by applying urea-formaldehyde and melamine urea-formaldehyde (Alma et al. 2005) reported that all studied properties of boards nearly met the minimum requirements according to TS EN 312-2 (1999) for general particleboards. Kadja et al. (2011) studied particleboards made from the stems of cotton plants using bone resin at the pressing temperature of $140{ }^{\circ} \mathrm{C}$ and revealed that the boards met the requirements of standard ANSI A 208.1 (1999) in terms of modulus of rupture (MOR) and modulus of elasticity (MOE) values with the rate of bone resin application of $10 \%$ and $12.5 \%$. Mixing cotton stalks with paulownia and industrial wood at different rates 
for particleboard production was conducted by Khanjanzadeh et al. (2012). The results indicated that the highest mechanical properties were achieved at cotton stalk/industrial wood and paulownia wood/industrial wood rates of $50 \mathrm{wt} \%$ and $70 \mathrm{wt} \%$, respectively.

The influence of a number of production parameters on the particleboard performance of boards manufactured from cotton stalks without bark was conducted by Nazerian et al. (2015). The outcome revealed that the MOR, MOE, and IB values of boards increased with increasing board density and press temperature. The increase in press closing speed results in increasing MOR but decreasing IB. Additionally, water absorption and thickness swelling decreased with increasing panel density and press temperature, while press closing speed had an insignificant effect on water absorption and thickness swelling. Optimization of the implementation process and physical properties of particleboard manufactured from bark-less cotton and kenaf stems using bone adhesive at different temperatures and rates of bone adhesive (Soulama et al. 2015) showed that the optimal temperature and resin content were $140{ }^{\circ} \mathrm{C}$ and $12.5 \%$, respectively. The panels' properties meet the requirements of the standard ANSI A 208.1 (1999) in terms of the MOR and MOE values, but TS did not meet the standard. Thickness swelling was almost four times higher than the standard requirement of $8 \%$ after $2 \mathrm{~h}$ of immersion in water. Nazerian et al. (2018) investigated blending cotton stalks with poplar wood for the core layer at different ratio levels and different ratios of melamine formaldehyde resin to urea formaldehyde as well as shelling ratios for particleboard production. The results of this investigation revealed that the maximum values of MOR, MOE, and IB were achieved when the ratio of melamine formaldehyde resin to urea formaldehyde was $18.3 \%$, the shelling ratio was $30.3 \%$, and the weight rate of poplar to cotton stalk in the core layer was $10.7 \%$.

The prior studies conducted on the manufacturing of cotton-stalk particleboards discussed above only considered stems of cotton stalk without bark and therefore did not account for the other important components of cotton stalks such as branches, bark, carpels, and cotton ball residues. The average bark of cotton stems has been shown to be $26 \mathrm{wt} \%$ of cotton stem mass (Li et al. 2012) representing a significant potential additional biomass resource. Removing bark from thin cotton stems is also technically difficult and adds cost. Moreover, the resin used in those studies was formaldehyde-based resin, which can release free formaldehyde during utilization. This will have detrimental impacts on human health. Consequently, a study on the manufacture of formaldehyde-free particleboards from whole cotton stalks is necessary.

The aim of this study is to: 1) Characterize cotton stalk morphology; 2) Investigate the effects of opening particle sizes $(20,10,8$, and $6 \mathrm{~mm})$ on the mechanical and physical properties of homogenous particleboard made of whole cotton stalks; and 3) Evaluate the influence of cotton ball residues at four different loadings $(0,5,10$, and $15 \mathrm{wt} \%)$ on particleboard performance.

\section{EXPERIMENTAL}

\section{Materials}

Resource characterization

The cotton stalks used in this research were harvested after less than 1 month since the cotton ball was harvested at Goodar, Queensland, Australia (WGS-84 coordinates: - 
28.4775 S, 150.2455 E). After harvesting, the cotton stalks were air-dried for two months to a moisture content of $20 \%$.

\section{Optimization of opening particle sizes}

After air-drying, whole cotton stalks were converted into chips using a commercial chipping machine (Hansa C7; Hamilton, New Zealand). The chips were milled into four different particle size categories by a laboratory cutting mill (SM 100; Retsch, Haan, Germany) using the four different sieve sizes: 20, 10, 8, and $6 \mathrm{~mm}$ (Fig. 1). Following this, the particles were shaken with a $0.3-\mathrm{mm}$ sieve to remove fine particles with a size smaller than $0.3 \mathrm{~mm}$.
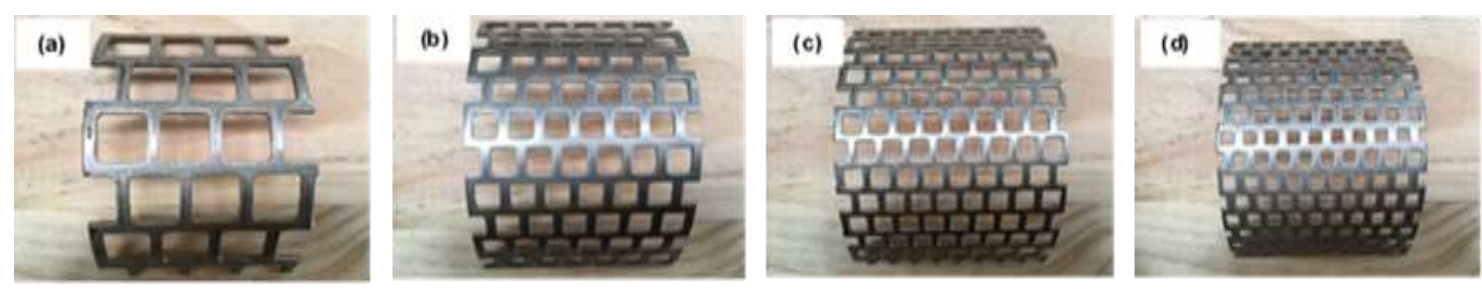

Fig. 1. Four different sieves: (a) $20 \mathrm{~mm}$, (b) $10 \mathrm{~mm}$, (c) $8 \mathrm{~mm}$, and (d) $6 \mathrm{~mm}$

The influence of cotton ball residues on performance of particleboards

Cotton ball residues were removed from the cotton stalks, and then the best performing opening size particles $(8 \mathrm{~mm})$ from the optimization of the opening particle size procedure was chosen to manufacture particles for this study. The cotton ball residues were added according to four different ratios $(0,5,10$, and $15 \mathrm{wt} \%)$ during the process of particle manufacturing.

\section{Methods}

Resource characterization

In order to characterize cotton stalk morphology, 100 cotton stalks were randomly selected and then conditioned at $20{ }^{\circ} \mathrm{C}$ and $65 \%$ relative humidity $(\mathrm{RH})$ to reach a moisture content of $12 \%$. Subsequently, some physical properties were measured including the number of branches, stem length, stem diameter, stalk mass, and each cotton stalk component mass. The following protocol was followed:

The overall length of each stalk was measured using a measuring tape. The diameter of each cotton stem was measured at the middle of the stem using a digital caliper. The largest diameter $d_{1}$ and the perpendicular diameter $d_{2}$ (perpendicular to $d_{1}$ ), were measured. The average of each stem was calculated according to Eq. 1,

$$
D(\mathrm{~mm})=\left(d_{1}+d_{2}\right) / 2
$$

where $D$ is the average stem diameter $(\mathrm{mm}), d_{1}$ is the largest diameter stem mid-point $(\mathrm{mm})$, and $d_{2}$ is the diameter perpendicular to $d_{1}(\mathrm{~mm})$.

To determine the weight proportion of each cotton stalk component, firstly the entire cotton stalk and each component of a cotton stalk were weighed. Eventually, the weight proportion of each cotton stalk component (stem, branches, carpel, and ball) was calculated according to Eq. 2,

$$
P(\%)=(\text { Cotton component mass } / \text { Cotton stalk mass }) \times 100
$$


where $P$ is percentage of the cotton component

Optimization of opening particle sizes and analysis of the distribution of particle sizes

After conditioning to a moisture content of $12 \%$, a sieve analysis was performed for each particle category with a laboratory shaker (Fig. 3). This was done to observe the particle size distribution and to understand the influence of particle size on particleboard properties. Each particle category was sorted into five sieve groups using four different metal sieves consisting of 3.15, 2, 1, and $0.5 \mathrm{~mm}$ (Fig. 2) opening sizes. Then, $100 \mathrm{~g}$ of particles were shaken for a duration of $10 \mathrm{~min}$ and five replications were performed. Finally, the distribution of particle size was calculated as a percentage according to Eq. 3 ,

$$
P_{\mathrm{i}}(\%)=\left(w_{\mathrm{i}} / w\right) \times 100
$$

where $P_{\mathrm{i}}$ is the percentage of particles on the sieve $i$ compared to total mass of particles $(\%), w_{\mathrm{i}}$ is the mass of particles on the sieve $i(\mathrm{~g})$, and $w$ is the total mass of particles $(\mathrm{g})$.

In order to determine the slenderness ratio of the particles, 100 particles were randomly selected from each sieve analysis group particle category and their length and thickness were measured using a digital caliper. The slenderness ratio of particles was calculated according to Eq. 4,

$$
S=l / d
$$

where $S$ is the slenderness ratio, $l$ is the length of a particle $(\mathrm{mm})$, and $d$ is thickness of a particle $(\mathrm{mm})$

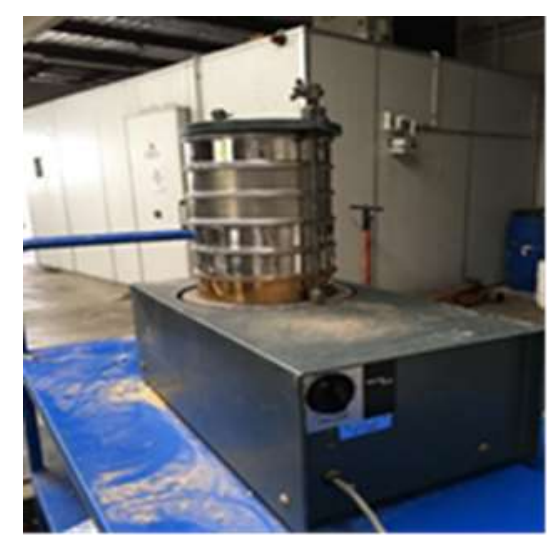

Fig. 2. Laboratory shaker

\section{Particleboard production and test}

After the particles were separated into size groups and the fines smaller than 0.3 $\mathrm{mm}$ were removed, all four types of particles were conditioned to $16 \%$ moisture content. The four types of homogenous particleboard, A, B, C, and D, according to the opening particle sizes of $20,10,8$, and $6 \mathrm{~mm}$, respectively, were manufactured with a target thickness of $12 \mathrm{~mm}$ and a density of $0.75 \mathrm{~g} / \mathrm{cm}^{3}$.

A wooden mold with the dimension of $28 \mathrm{~cm} \times 32 \mathrm{~cm}$ was used for mat forming. Three replications of each type were made. An emulsifiable polymeric isocyanate adhesive (eMDI) I-BOND® PB EM 4352 provided by Huntsman (Huntsman Polyurethanes Australia, Hillsdale, Australia) was applied such that $6 \%$ of adhesive was used as a ratio of the oven-dry weight of the particles. The resin was sprayed directly onto the particles using 
an atomized spray nozzle during the initial stage of the 5 min long mixing process. Four board types were manufactured using a hot press (Carver 3856, Wabash, IN, USA) with board production parameters shown in Table 2. The eMDI resin was applied in this research. He and Yan (2005) investigated effect of moisture content on curing kinetics of pMDI resin and wood mixture. Results indicated that the curing rate increased noticeably with increasing moisture content of raw materials. Mat moisture content between 10.8\% and $18.5 \%$ can be applied isocyanate resins (Cai et al. 2006). Frazier (2003) suggested that mat moisture content level ranging from $12 \%$ to $20 \%$ will yield acceptable board performance with pMDI resin. Moreover, the higher moisture content levels mean that the particles become bonded together under moisture conditions that are closer to the those under which they will be used (in-service moisture content of the particleboard). This can be advantageous for reducing the level of residual stresses, which originate from the moisture uptake after manufacturing. In addition, when moisture content of raw materials is low, the particle will absorb more adhesive, which can lead to lack of adhesive on particle surface. Consequently, mat moisture content of $16 \%$ was chosen for this study. It is important to note that eMDI, unlike UF adhesive, does not contain any water. Hence, the moisture content of the mat should not be directly compared with the raw material moisture content reported in studies using UF adhesives, as these values do not include the additional water that is added as part of the adhesive application process.

Table 2. Experimental Design for Optimization of Opening Particle Sizes

\begin{tabular}{|c|c|c|c|c|}
\hline Board Types & $\begin{array}{c}\text { Press } \\
\text { Temperature } \\
\left({ }^{\circ} \mathrm{C}\right)\end{array}$ & $\begin{array}{c}\text { Pressing } \\
\text { Time } \\
(\mathrm{min})\end{array}$ & $\begin{array}{c}\text { Press } \\
\text { Pressure } \\
(\mathrm{MPa})\end{array}$ & $\begin{array}{c}\text { Mat Moisture } \\
\text { Content } \\
(\%)\end{array}$ \\
\hline A (20-mm opening particle size) & 170 & 3 & 2 & 16 \\
\hline B (10-mm opening particle size) & 170 & 3 & 2 & 16 \\
\hline C (8-mm opening particle size) & 170 & 3 & 2 & 16 \\
\hline D (6-mm opening particle size) & 170 & 3 & 2 & 16 \\
\hline
\end{tabular}

The press pressure was released slowly over the duration of one minute after 3 minutes of pressing time. The slow pressure release was necessary to avoid delamination due to a rapid release of the steam pressure. It is important to note that the boards produced in this research are relatively small $(280-\mathrm{mm} \times 320-\mathrm{mm})$. When upscaling the manufacturing process, care should be taken to adequately manage the steam pressure. Upscaling the process may require changes to the overall pressing time and un-moulding process.

After being taken from the hot press, the boards were placed in the ventilation area for at least two weeks for the balancing of the moisture content, relieving internal stress, and allowing full resin cure, before trimming the edges and cutting test pieces.

The size of test pieces and methods of testing were compliant with Australian/New Zealand standard AS/NZS 4266.1 (2017). The test specimens were conditioned in a conditioning cabinet at $20^{\circ} \mathrm{C}$ and $65 \% \mathrm{RH}$ to reach approximately $12 \%$ moisture content. Both MOR and MOE were conducted according to Australian/New Zealand standard AS/NZS 4266.1 (2017) section 7, and the number of test specimens was 9 for each board type. The IB was performed in accordance with AS/NZS 4266.1 (2017) sections 8 and 9, and specimens were tested for each board category. Thickness swelling tests after $2 \mathrm{~h}$ and $24 \mathrm{~h}$ immersion in water on 9 test pieces was conducted for each type of board following 
AS/NZS 4266.1 (2017) section 10. The density of boards was determined in accordance with AS/NZS 4266.1 (2017) section 6.

The results of this research were analyzed using an analysis of variance (ANOVA) multiple comparison test with a confidence interval of 95\% using Minitab Statistical Software (Minitab LLC, v.19, State College, PA, USA).

The influence of cotton ball residues on performance of particleboards

After the particles were generated using a sieve size of $8 \mathrm{~mm}$, with all the fines smaller than $0.3 \mathrm{~mm}$ removed, all particles with different cotton ball residue ratios $(0,5$, 10 , and $15 \mathrm{wt} \%$ ) were conditioned to $16 \%$ moisture content. Four single layer particleboard types were prepared for this study with a target thickness of $12 \mathrm{~mm}$ and a density of 0.75 $\mathrm{g} / \mathrm{cm}^{3}$ as shown in Table 3 . Three replications of each type were made.

Table 3. Experimental Design for the Influence of Cotton Ball Residues

\begin{tabular}{|c|c|c|c|c|}
\hline Board Types & $\begin{array}{c}\text { Press } \\
\text { Temperature } \\
\left({ }^{\circ} \mathrm{C}\right)\end{array}$ & $\begin{array}{c}\text { Pressing } \\
\text { Time } \\
(\mathrm{min})\end{array}$ & $\begin{array}{c}\text { Press } \\
\text { Pressure } \\
(\mathrm{MPa})\end{array}$ & $\begin{array}{c}\text { Mat Moisture } \\
\text { Content } \\
(\%)\end{array}$ \\
\hline $\mathrm{E}(0 \mathrm{wt} \%$ cotton ball residues $)$ & 170 & 3 & 3 & 16 \\
\hline $\mathrm{F}(5 \mathrm{w} \%$ cotton ball residues $)$ & 170 & 3 & 3 & 16 \\
\hline $\mathrm{G}(10 \mathrm{wt} \%$ cotton ball residues $)$ & 170 & 3 & 3 & 16 \\
\hline $\mathrm{H}(15 \mathrm{wt} \%$ cotton ball residues $)$ & 170 & 3 & 3 & 16 \\
\hline
\end{tabular}

The testing methodology described in "Optimization of opening particle sizes" was followed again for this investigation.

\section{RESULTS AND DISCUSSION}

\section{Resource characterization}

The results obtained from the measurement of 100 cotton stalk samples demonstrated that the minimum and maximum length of stems were $160 \mathrm{~mm}$ and $890 \mathrm{~mm}$, respectively. The smallest average diameter at the middle of the stem was $5.03 \mathrm{~mm}$ and the largest was $10.88 \mathrm{~mm}$. The resulting mean values are shown in Table 4.

Table 4. Some Physical Properties of Cotton Stalks

\begin{tabular}{|c|c|c|}
\hline Components & Range & Average \\
\hline Stem Length $(\mathrm{mm})$ & 160 to 890 & $686.75(119.05)$ \\
\hline Stem Diameter $(\mathrm{mm})$ & 5.03 to 10.88 & $7.52(0.92)$ \\
\hline Mass of One Stalk $(\mathrm{g})$ & 12.30 to 144.50 & $51.12(25.75)$ \\
\hline Mass of Branches on One Stalk $(\mathrm{g})$ & 7.30 to 43.57 & $23.53(7.14)$ \\
\hline Mass of Cotton Ball Resides on One Stalk $(\mathrm{g})$ & 2.67 to 55.67 & $17.00(11.86)$ \\
\hline Mass of Cotton Carpel Per One Stalk $(\mathrm{g})$ & 0 to 13.43 & $2.70(3.19)$ \\
\hline Number of Branches Per One Stalk & 1.40 to 26.70 & $7.89(7.23)$ \\
\hline \multicolumn{2}{|l}{} \\
Note: Standard deviation is presented in parenthesis \\
\hline
\end{tabular}

The average percentage of each component of the cotton stalk by mass is illustrated in Fig. 3 and shows that the largest proportion is made up of the cotton stem (46 wt $\%$ ), followed by branches (33 wt \%), and the smallest is cotton ball residues ( $5 \mathrm{wt} \%)$. The ratio of cotton bark to total mass ratio was reported at $26 \mathrm{wt} \%$ of the cotton stem mass (Li et al. 
2012). Consequently, in the event that only the cotton stem without bark is used, the total utilization of biomass is less than $50 \mathrm{wt} \%$. This is not only uneconomic, but the removal of bark from thin cotton stalks is also technically challenging and adds to the overall processing costs.

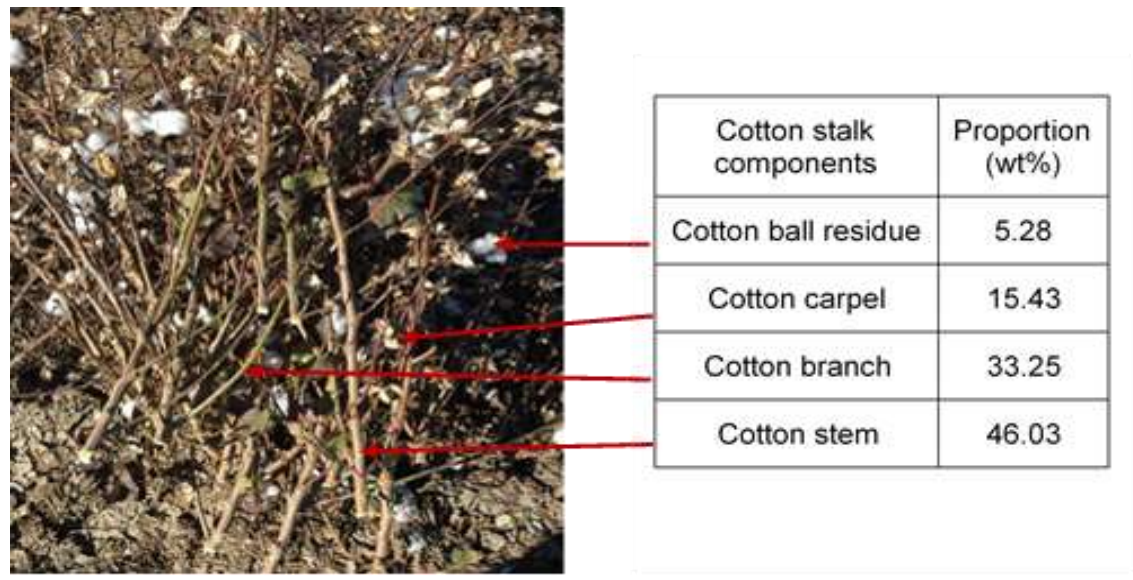

Fig. 3. Average weight proportion of cotton component

It can be seen from Table 1, the main chemical composition of cotton stalks (hemicellulose, cellulose, and lignin proportion) showed minimal variation although they were collected from different locations: Kahramanmaras regions in Turkey (Ertaş et al. 2010; Tutus et al. 2010) and Bobo-dioulasso area in Burkina Faso (Soulama et al. 2015). Therefore, the main chemical composition of cotton stalks used in this study is believed to be around the values presented in Table 1.

Optimization of opening particle sizes and analysis of the distribution of particle sizes

The average distribution of particles by weight and standard deviation of the four different opening particle size categories $(20,10,8$, and $6 \mathrm{~mm})$ are shown in Table 5. Overall, the particle size distribution varied between particle categories. The widest distribution of particle sizes was recorded in the $20 \mathrm{~mm}$ particle category, while the narrowest distribution was recorded for the 8-mm opening particle size category.

Table 5. Average Weight Distribution of Various Particle Size Categories

\begin{tabular}{|c|c|c|c|c|c|}
\hline \multirow[b]{2}{*}{$\begin{array}{c}\text { Particle } \\
\text { Categories }\end{array}$} & \multicolumn{5}{|c|}{ Average Proportion (\%) } \\
\hline & $\begin{array}{c}\text { Particles on } \\
\text { 3.15-mm } \\
\text { Sieve }\end{array}$ & $\begin{array}{l}\text { Particles } \\
\text { Between } \\
3.15-\text { and } \\
2.0-\mathrm{mm} \\
\text { Sieves }\end{array}$ & $\begin{array}{c}\text { Particles } \\
\text { Between 2.0- } \\
\text { and 1.0-mm } \\
\text { Sieves }\end{array}$ & $\begin{array}{c}\text { Particle } \\
\text { Between 1.0- } \\
\text { and 0.5-mm } \\
\text { Sieves }\end{array}$ & $\begin{array}{c}\text { Particle } \\
\text { Passed } \\
\text { Through 0.5- } \\
\text { mm Sieves }\end{array}$ \\
\hline $20 \mathrm{~mm}$ & $51.89(4.08)$ & $17.19(1.03)$ & $13.72(1.09)$ & $11.43(1.87)$ & $5.77(1.32)$ \\
\hline $10 \mathrm{~mm}$ & $27.63(1.57)$ & $24.62(2.42)$ & $22.03(1.52)$ & $19.21(1.16)$ & $6.51(0.33)$ \\
\hline $8 \mathrm{~mm}$ & $18.83(1.61)$ & $25.45(2.23)$ & $26.87(1.53)$ & $21.45(0.92)$ & $7.40(0.32)$ \\
\hline $6 \mathrm{~mm}$ & $8.02(0.50)$ & $21.57(3.96)$ & $30.03(3.20)$ & $27.76(0.82)$ & $12.61(0.49)$ \\
\hline
\end{tabular}

The average slenderness ratio measured from 100 particles of each sieve analysis group is shown in Table 6. There were noticeably different slenderness ratio values of particles between sieve analysis groups. The highest particle slenderness ratio (18.6) was 
found in the sieve analysis group between sieve sizes of $2.0 \mathrm{~mm}$ and $1.0 \mathrm{~mm}$. This figure was almost 2.5 times higher than the smallest one (7.7) that was recorded in the sieve analysis group of particles that passed through the $0.5-\mathrm{mm}$ sieve.

Table 6. Average Slenderness Ratio of Sieve Analysis Groups

\begin{tabular}{|c|c|c|c|c|c|}
\hline $\begin{array}{c}\text { Analysis } \\
\text { Sieve Groups }\end{array}$ & $\begin{array}{c}\text { Particle on } \\
\text { 3.15-mm } \\
\text { Sieve }\end{array}$ & $\begin{array}{c}\text { Particles } \\
\text { Between } \\
\begin{array}{c}3.15-\text { and } \\
2.0-\mathrm{mm} \\
\text { Sieves }\end{array}\end{array}$ & $\begin{array}{c}\text { Particles } \\
\text { Between 2.0- } \\
\text { and 1.0-mm } \\
\text { Sieves }\end{array}$ & $\begin{array}{c}\text { Particles } \\
\text { Between 1.0- } \\
\text { and 0.5-mm } \\
\text { Sieves }\end{array}$ & $\begin{array}{c}\text { Particles } \\
\text { Passed } \\
\text { Through 0.5- } \\
\text { mm Sieves }\end{array}$ \\
\hline $\begin{array}{c}\text { Slenderness } \\
\text { Ratio }\end{array}$ & 9.15 & 12.02 & 18.66 & 14.00 & 7.75 \\
\hline
\end{tabular}

Based on the average weight distribution in each opening particle size category (Table 5) and average slenderness ratio of each sieve analysis category of particles (Table 6 ), the average slenderness ratio of each opening particle size category was calculated, as shown in Table 7.

Table 7. Average Slenderness Ratio of Various Opening Particle Size Categories

\begin{tabular}{|c|c|c|c|c|}
\hline $\begin{array}{c}\text { Particle } \\
\text { Categories }\end{array}$ & $\begin{array}{c}\text { Opening Size of } \\
20 \mathrm{~mm}\end{array}$ & $\begin{array}{c}\text { Opening Size of } \\
10 \mathrm{~mm}\end{array}$ & $\begin{array}{c}\text { Opening Size of } \\
8 \mathrm{~mm}\end{array}$ & $\begin{array}{c}\text { Opening Size of } \\
6 \mathrm{~mm}\end{array}$ \\
\hline $\begin{array}{c}\text { Slenderness } \\
\text { Ratio }\end{array}$ & 11.4 & 12.8 & 13.8 & 13.7 \\
\hline
\end{tabular}

It can be seen from Table 7 that the particle categories with opening particle sizes of $8 \mathrm{~mm}$ and $6 \mathrm{~mm}$ had almost the same slenderness ratio. The particle category with an opening particle size of $8 \mathrm{~mm}$ had the largest slenderness ratio, whereas the particle category with an opening particle size of $20 \mathrm{~mm}$ had the smallest slenderness ratio.

\section{Mechanical and physical properties of four particleboard types}

Four categories of cotton stalk particles using the four different size sieves $(20,10$, 8 , and $6 \mathrm{~mm}$ ) were prepared for this study. The four homogenous types of boards (A, B, C, and D) in accordance with the four different particle categories were fabricated. It is widely known that one of the important factors that influences mechanical properties of particleboard is board density. The results of this research were analyzed using analysis of variance (ANOVA) multiple comparison tests with a confidence interval of $95 \%$.

Table 8. Density ANOVA Multiple Comparison Based on Tukey's Significant Different Test

\begin{tabular}{|c|c|c|}
\hline \multirow{2}{*}{ Board Types } & $\begin{array}{c}\text { Average Density } \\
\left(\mathrm{g} / \mathrm{cm}^{3}\right)\end{array}$ & $\begin{array}{c}\text { Groups Subset for } \alpha= \\
0.05\end{array}$ \\
\cline { 3 - 3 } & $0.759(0.016)$ & 1 \\
\hline D & $0.759(0.022)$ & $\mathrm{x}$ \\
\hline $\mathrm{B}$ & $0.756(0.017)$ & $\mathrm{x}$ \\
\hline $\mathrm{C}$ & $0.753(0.019)$ & $\mathrm{x}$ \\
\hline A & $\mathrm{x}$ \\
\hline \multicolumn{2}{|l}{} \\
\hline
\end{tabular}


The results from density analysis of the variance among four types of boards are shown in Table 8, which revealed that the density differences between the four types of manufactured boards were insignificant. Therefore, its impact on mechanical properties of boards was not taken into further consideration in this research.

The influence of particle size on the MOR and MOE expressed by the four types of particleboards (type A with opening particle size of $20 \mathrm{~mm}$, type B with opening particle size of $10 \mathrm{~mm}$, type $C$ with opening particle size of $8 \mathrm{~mm}$, and type $\mathrm{D}$ with opening particle size of $6 \mathrm{~mm}$ ) is shown in Fig. 4. The thickness of the manufactured boards was $14 \mathrm{~mm}$, and the ratio between the distance between the two supports and the thickness of test piece was 13.
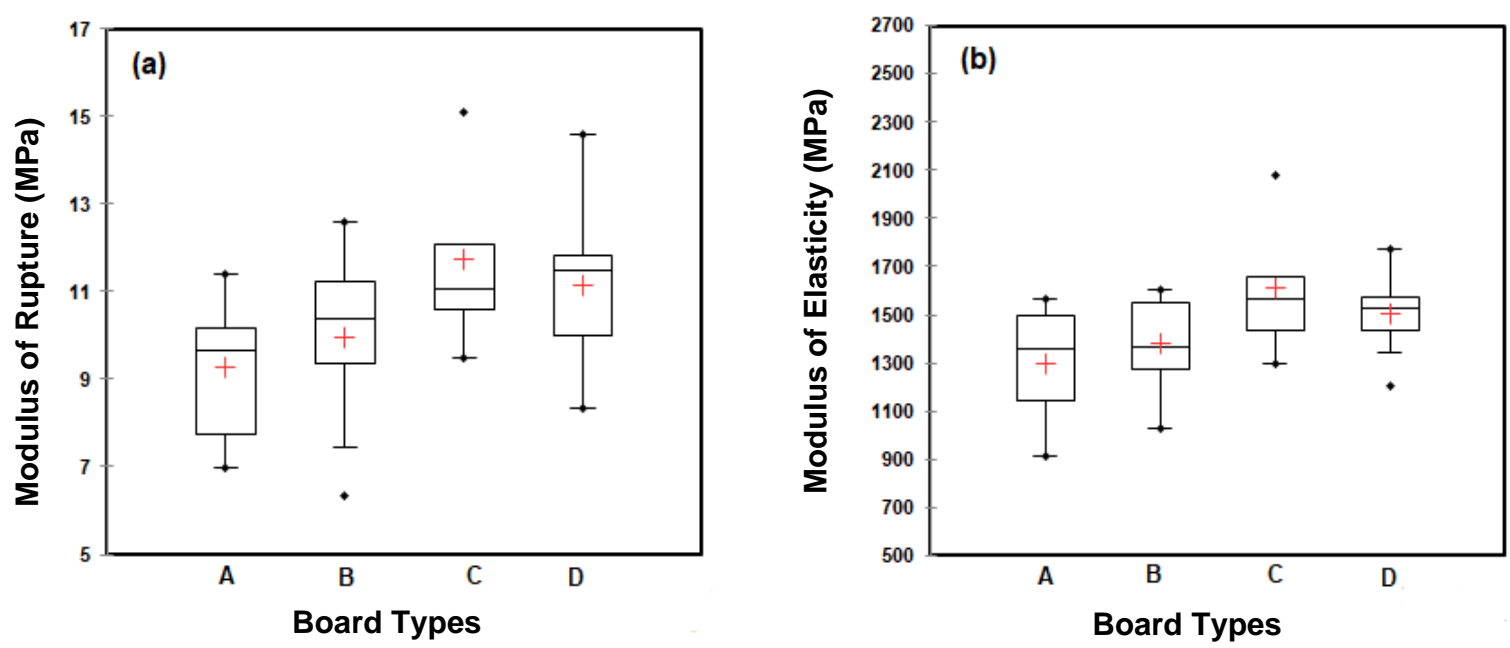

Fig. 4. Effect of opening particle size on (a) MOR and (b) MOE

It can be seen from Fig. 4 that the average value of MOR and MOE first increased and then decreased with decreasing opening particle size. The mean MOR value went up from 9.26 MPa to 11.73 MPa and then declined to $11.14 \mathrm{MPa}$ while the average value of MOE initially increased from $1300 \mathrm{MPa}$ to $1612 \mathrm{MPa}$ and then after that decreased to 1500 $\mathrm{MPa}$ with a decrease in the opening particle size from $20 \mathrm{~mm}$ to $6 \mathrm{~mm}$. The highest MOR and MOE were observed in the particleboard type $C$ (8-mm opening particle size). The lowest value of MOR and MOE were recorded in the particleboard type A (20-mm opening particle size). The increase of MOR and MOE from board type A to board type $\mathrm{C}$ was likely a consequence of an increase in mean slenderness ratio of particles as shown in Table 7. The MOR and MOE values of board type D were lower than that of board type C although the particles had almost the same average slenderness ratio. This can possibly be explained by the fact that board type $\mathrm{D}$ had a higher percentage of fine particles (smaller than $0.5 \mathrm{~mm}$ ). Consequently, the amount of adhesive per particle surface area is lower, which translates to lower mechanical properties.

The analysis of variance of MOR and MOE among the four types of boards is shown in Table 9. These results revealed that only the board type $\mathrm{C}$ and type $\mathrm{A}$ had significantly different values of both MOR and MOE. There were insignificant differences of MOR and MOE values for the rest of the pairwise comparisons. 
Table 9. MOR and MOE ANOVA Multiple Comparison Based on Tukey's Significant Difference Test

\begin{tabular}{|c|c|c|c|c|c|c|c|}
\hline \multirow{2}{*}{$\begin{array}{c}\text { Board } \\
\text { Types }\end{array}$} & $\begin{array}{c}\text { Average of MOR } \\
(\mathrm{MPa})\end{array}$ & $\begin{array}{c}\text { Subset for } \alpha= \\
0.05\end{array}$ & $\begin{array}{c}\text { Board } \\
\text { Types }\end{array}$ & \multicolumn{2}{c|}{$\begin{array}{c}\text { Average of MOE } \\
\text { (MPa) }\end{array}$} & \multicolumn{2}{c|}{$\begin{array}{c}\text { Groups Subset } \\
\text { for } \alpha=0.05\end{array}$} \\
\cline { 3 - 8 } & 1 & 2 & & & 1 & 2 \\
\hline C & $11.73(2.05)$ & $\mathrm{x}$ & & $\mathrm{C}$ & $1612.87(267.6)$ & $\mathrm{x}$ & \\
\hline $\mathrm{D}$ & $11.14(1.85)$ & $\mathrm{x}$ & $\mathrm{x}$ & $\mathrm{D}$ & $1500.9(167.84)$ & $\mathrm{x}$ & $\mathrm{x}$ \\
\hline $\mathrm{B}$ & $9.94(1.99)$ & $\mathrm{x}$ & $\mathrm{x}$ & $\mathrm{B}$ & $1381.73(195.3)$ & $\mathrm{x}$ & $\mathrm{x}$ \\
\hline $\mathrm{A}$ & $9.26(1.5)$ & & $\mathrm{x}$ & $\mathrm{A}$ & $1300.47(244.9)$ & & $\mathrm{x}$ \\
\hline
\end{tabular}

Figure 5 shows the effect of particle size on IB of the four particleboard types (A, $\mathrm{B}, \mathrm{C}$, and D) according to the opening size of particles of $20,10,8$, and $6 \mathrm{~mm}$. It was observed that board types $C$ and $D$ had almost the same average values of IB strength $(0.66$ and $0.65 \mathrm{MPa}$, respectively), which were the highest IB among the board types tested.

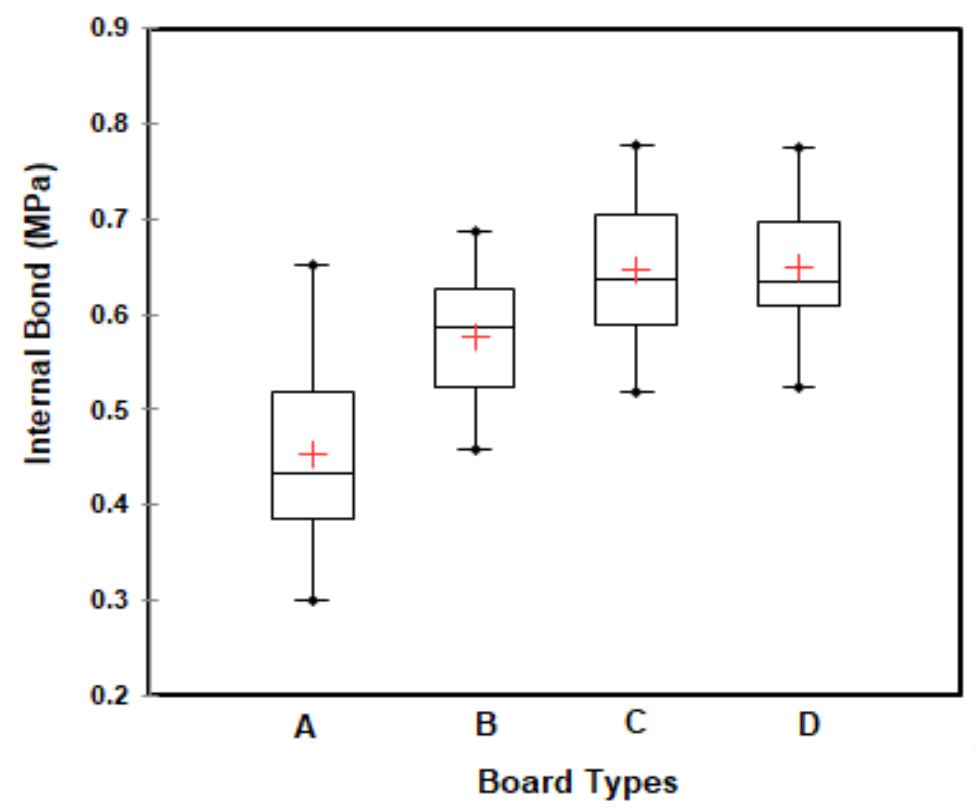

Fig. 5. Effect of opening particle size on IB

The lowest average value of IB strength was recorded for board type A with 0.46 $\mathrm{MPa}$. This could be explained as board type A, having the highest proportion (52\%) of particles on the sieve size $3.15 \mathrm{~mm}$ (Table 5), which were much thicker and wider in comparison with particles which passed through that sieve size. When other technological parameters are constant, the increase in thickness and width of particle results in the decrease in internal bond strength (Fu 1998).

According to the results from the analysis of variance as shown in Table 10, there was no significant difference in the average IB values of boards type $C$, type $D$, and type $B$. In contrast, the average IB value of board type A was significantly lower than that of type $\mathrm{C}$, type $\mathrm{D}$, and type $\mathrm{B}$. 
Table 10. IB ANOVA Multiple Comparison Based on Tukey's Significant Different Test

\begin{tabular}{|c|c|c|c|}
\hline \multirow{2}{*}{ Board Types } & $\begin{array}{c}\text { Average of IB } \\
(\mathrm{MPa})\end{array}$ & Groups Subset for $\alpha=0.05$ \\
\cline { 3 - 4 } & $0.66(0.09)$ & 1 & 2 \\
\hline C & $0.65(0.08)$ & $\mathrm{x}$ & \\
\hline D & $0.58(0.08)$ & $\mathrm{x}$ & \\
\hline B & 0.58 & $\mathrm{x}$ \\
\hline A & $0.46(0.11)$ & & \\
\hline
\end{tabular}

Thickness swelling is a key parameter characterizing the dimensional stability of particleboard under wet conditions. The influence of particle size on average thickness swelling of boards after $2 \mathrm{~h}$ and $24 \mathrm{~h}$ immersion in water is illustrated in Fig. 6. Thickness swelling after $2 \mathrm{~h}$ and $24 \mathrm{~h}$ increased with a decrease in opening particle sizes from $20 \mathrm{~mm}$ to $10 \mathrm{~mm}$ and then decreased with a continuing decrease in the opening particle size to 8 $\mathrm{mm}$. Subsequently, thickness swelling increased again with a continuing decrease in the opening particle size to $6 \mathrm{~mm}$. For all four type of boards, the thickness swelling after $2 \mathrm{~h}$ was much lower than that of $24 \mathrm{~h}$.
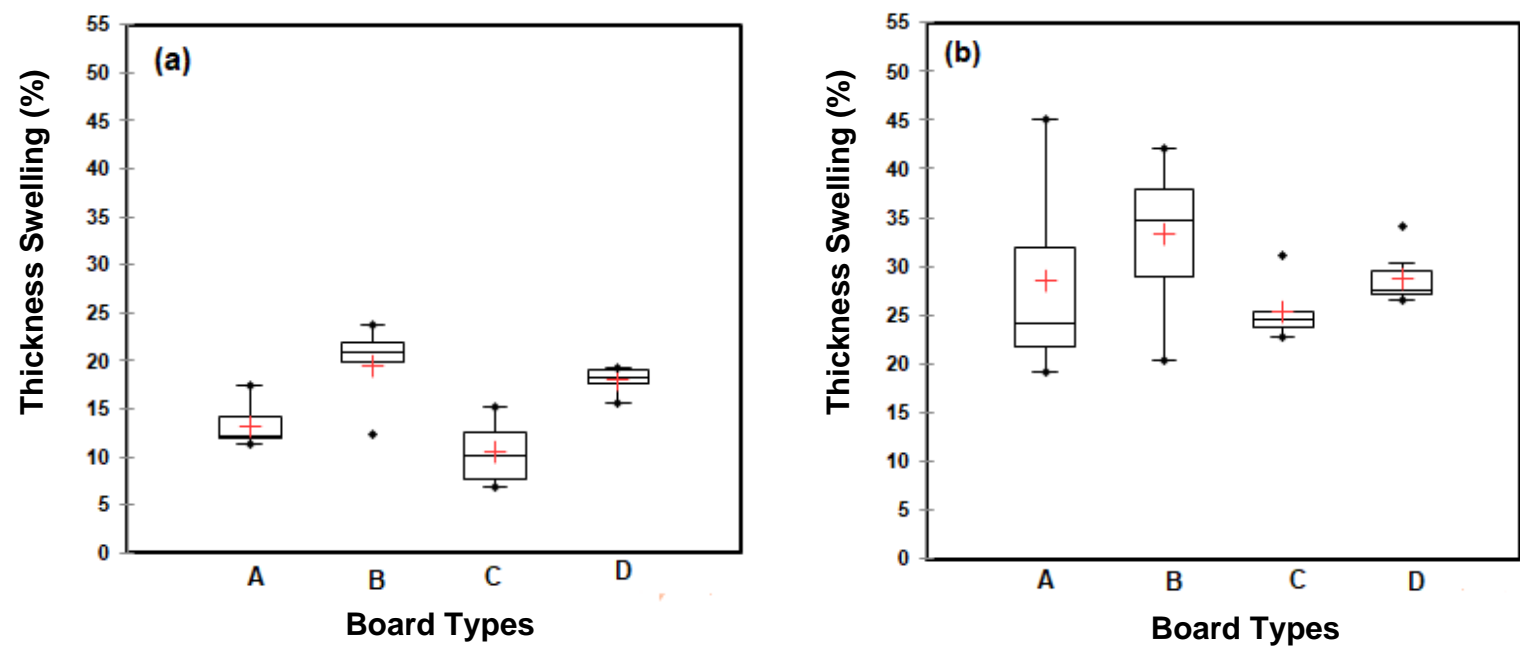

Fig. 6. Effect of opening particle size on TS after (a) $2 \mathrm{~h}$ and (b) $24 \mathrm{~h}$

The result from analysis of variance in Table 11 shows that there were insignificant differences in average thickness swelling values among the four type of boards after $24 \mathrm{~h}$ of immersion in water. This can be explained through the fact that during the $24 \mathrm{~h}$ immersion, all particles had sufficient time to make contact with water, leading to a more even expansion.

Nevertheless, after $2 \mathrm{~h}$ of immersion in water, the average thickness swelling of board type A and type $\mathrm{C}$ was significantly lower than that of board type $\mathrm{B}$ and type $\mathrm{D}$, as shown in Table 11. The probable explanation for that is the particles in board type A had the highest ratio of particles on the sieve size of $3.15 \mathrm{~mm}(52 \mathrm{wt} \%)$. This figure was also much higher than those in board types B (27 wt \%), C (18 wt \%), and D (8.02 wt \%). It is well known that larger particle sizes exhibit slower swelling rates compared to finer particle sizes. Conversely, board type D had the highest proportion of fine particles (40 wt\% opening particle size smaller than $1 \mathrm{~mm}$ ). This explains why board type D had the highest 
thickness swelling after $2 \mathrm{~h}$ of immersion in water. Compared to board type $\mathrm{C}$, board type $\mathrm{B}$ had a much higher ratio of large particles (particles remain on sieve size $3.15 \mathrm{~mm}$ (27 $\mathrm{wt} \%$ board type B, $18 \mathrm{wt} \%$ board type C)). However, they had insignificant differences in the proportion of fine particles (opening particle size smaller than $1 \mathrm{~mm}$ (29 wt $\%$ board type B, $26 \mathrm{wt} \%$ board type C)). This could have led to larger voids in board type B that allowed water to more easily penetrate inside the board compared to board type $\mathrm{C}$. This could explain why board type $\mathrm{C}$ had much lower thickness swelling than that of board type B.

Table 11. TS $2 \mathrm{~h}$ and TS $24 \mathrm{~h}$ ANOVA Multiple Comparison Based on Tukey's Significant Difference Test

\begin{tabular}{|c|c|c|c|c|c|c|}
\hline \multirow{2}{*}{$\begin{array}{c}\text { Board } \\
\text { Types }\end{array}$} & $\begin{array}{c}\text { Average of TS } 2 \mathrm{~h} \\
(\%)\end{array}$ & $\begin{array}{c}\text { Groups Subset } \\
\text { for } \alpha=0.05\end{array}$ & \multirow{2}{*}{$\begin{array}{c}\text { Board } \\
\text { Types }\end{array}$} & $\begin{array}{c}\text { Average of TS 24 } \mathrm{h} \\
(\%)\end{array}$ & $\begin{array}{c}\text { Groups Subset } \\
\text { for } \alpha=0.05\end{array}$ \\
\cline { 3 - 4 } & 1 & 2 & & $\mathrm{X}$ & $33.32(7.08)$ & 1 \\
\hline $\mathrm{B}$ & $19.55(4.19)$ & $\mathrm{x}$ & & $\mathrm{B}$ & $\mathrm{X}$ \\
\hline $\mathrm{D}$ & $18.02(1.28)$ & $\mathrm{X}$ & & $\mathrm{D}$ & $28.75(2.4)$ & $\mathrm{X}$ \\
\hline $\mathrm{A}$ & $13.23(2.13)$ & & $\mathrm{x}$ & $\mathrm{A}$ & $28.54(9.62)$ & $\mathrm{X}$ \\
\hline $\mathrm{C}$ & $10.58(3.07)$ & & $\mathrm{x}$ & $\mathrm{C}$ & $25.36(7.08)$ & $\mathrm{X}$ \\
\hline
\end{tabular}

The influence of cotton ball residues on performance of particleboards

Four homogenous types of boards including E, F, G, and $\mathrm{H}$ according to $0,5,10$, and $15 \mathrm{wt} \%$ cotton ball residues using 8-mm opening particle sizes (chosen based on its overall superior mechanical properties shown previously) were manufactured to investigate how cotton ball residues impact the performance of boards. The target density of all boards in this investigation was $0.75 \mathrm{~g} / \mathrm{cm}^{3}$. The variation in densities was small and insignificant (Table 12), and consequently the density change impacting mechanical properties of boards was not considered.

Table 12. Density ANOVA Multiple Comparison Based on Tukey's Significant Different test

\begin{tabular}{|c|c|c|}
\hline \multirow{2}{*}{ Board Types } & $\begin{array}{c}\text { Average Density } \\
\left(\mathrm{g} / \mathrm{cm}^{3}\right)\end{array}$ & Groups Subset for $\alpha=0.05$ \\
\cline { 3 - 3 } & $0.762(0.017)$ & $\mathrm{x}$ \\
\hline $\mathrm{E}$ & $0.758(0.013)$ & $\mathrm{x}$ \\
\hline $\mathrm{G}$ & $0.753(0.012)$ & $\mathrm{x}$ \\
\hline $\mathrm{H}$ & $0.750(0.021)$ & $\mathrm{x}$ \\
\hline $\mathrm{F}$ & \multicolumn{2}{|l}{} \\
\hline \multicolumn{2}{|l|}{ Note: Standard deviation is presented in parentheses } \\
\hline
\end{tabular}

Figure 7 shows the average, maximum, and minimum values of MOR and MOE for the four types of particleboards with various proportions of cotton ball residues: $\mathrm{E}(0$ $\mathrm{wt} \%), \mathrm{F}(5 \mathrm{wt} \%), \mathrm{G}(10 \mathrm{wt} \%)$, and $\mathrm{H}(15 \mathrm{wt} \%)$. The average MOR and MOE decreased with the increasing cotton ball residue load. The average MOR value reduced from 12.4 MPa with boards without cotton ball residue to $9.67 \mathrm{MPa}$ with boards containing $15 \mathrm{wt} \%$ of cotton ball residues. The average MOE decreased from 1871 to $1602 \mathrm{MPa}$ in the same boards. The result from the ANOVA in Table 15 shows the average value of MOR of boards without cotton ball residue was significantly higher than those of boards containing $5 \mathrm{wt} \%, 10 \mathrm{wt} \%$, and $15 \mathrm{wt} \%$ cotton ball residues. The average values of MOE also reduced with increasing cotton ball rates; however, the decrease was not significant when the cotton 
ball load increased by up to $10 \mathrm{wt} \%$ (Table 13). The results are conclusive overall and suggest that cotton ball residues clearly have a negative influence on the MOR and MOE
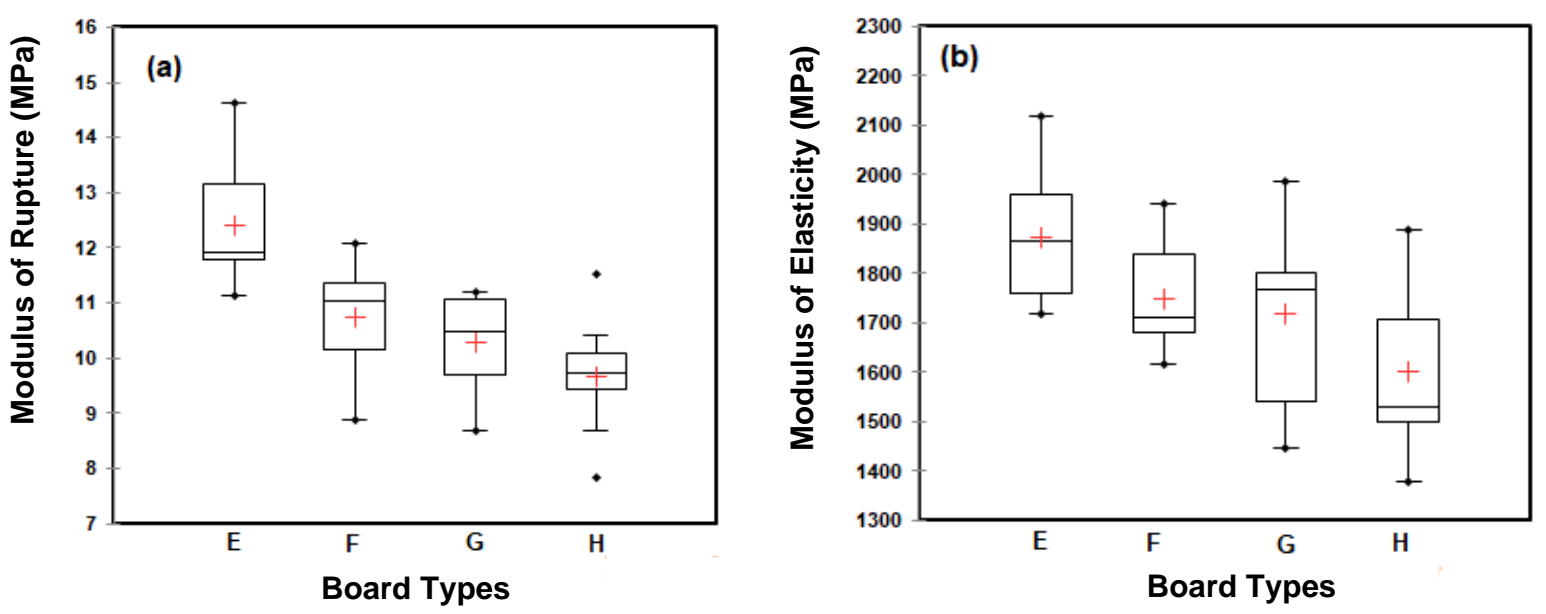

Fig. 7. Effect of cotton ball residue ratios on (a) MOR and (b) MOE

Cotton balls (cotton fiber) contain $90 \%$ cellulose and $4 \%$ of hemicellulose (Müssig and Haag 2015). High cellulose content can lead to an increase in the mechanical properties of particleboard, while high hemicellulose can have detrimental effects on mechanical properties of particleboard (Sar1 et al. 2014). However, the increasing ratio of cotton ball residues led to a reduction of MOR and MOE. The probable reasons for this phenomenon are as follows: 1) The wettability of cotton fibers is poor, leading to poor bond strength between the cotton fibres themselves and also between the cotton fiber and cotton stalks; 2) The cotton ball residues were observed to roll together during the adhesive mixing process, as shown in Fig. 8, resulting in a decrease in the slenderness ratio; 3) The cotton fiber exists only as single fibers and its density is 1.5 to $1.6 \mathrm{~g} / \mathrm{cm}^{3}$ (Müssig and Haag 2015) while the density of cotton stalks is low with approximately 0.31 to $0.32 \mathrm{~g} / \mathrm{cm}^{3}$ at a moisture content of $0 \%(\mathrm{Fu} 1998)$. An increase in the ratio of cotton balls reduces compaction rate (the relationship between the raw material's density and the final density of the particleboard). A previous study has shown that a higher compaction rate generally leads to superior mechanical properties of particleboard (Dias et al. 2005).

Table 13. MOR and MOE ANOVA Multiple Comparison Based on Tukey's Significant Difference Test

\begin{tabular}{|c|c|c|c|c|c|c|c|}
\hline \multirow[t]{2}{*}{$\begin{array}{l}\text { Board } \\
\text { Types }\end{array}$} & \multirow[t]{2}{*}{$\begin{array}{l}\text { Average of MOR } \\
(\mathrm{MPa})\end{array}$} & \multicolumn{2}{|c|}{$\begin{array}{c}\text { Groups } \\
\text { Subset for } \alpha= \\
0.05\end{array}$} & \multirow[t]{2}{*}{$\begin{array}{l}\text { Board } \\
\text { Types }\end{array}$} & \multirow[t]{2}{*}{$\begin{array}{c}\text { Average of MOE } \\
(\mathrm{MPa})\end{array}$} & \multicolumn{2}{|c|}{$\begin{array}{l}\text { Groups Subset } \\
\text { for } \alpha=0.05\end{array}$} \\
\hline & & 1 & 2 & & & 1 & 2 \\
\hline$E$ & $12.40(1.14)$ & $x$ & & $E$ & $1871.88(132.90)$ & $x$ & \\
\hline $\mathrm{F}$ & $10.72(1.02)$ & & $x$ & $\mathrm{~F}$ & $1747.55(112.84)$ & $x$ & $x$ \\
\hline G & $10.29(0.91)$ & & $\mathrm{x}$ & G & $1720.26(184)$ & $x$ & $\mathrm{x}$ \\
\hline $\mathrm{H}$ & $9.67(1.04)$ & & $x$ & $\mathrm{H}$ & $1602.47(166.47)$ & & $x$ \\
\hline
\end{tabular}




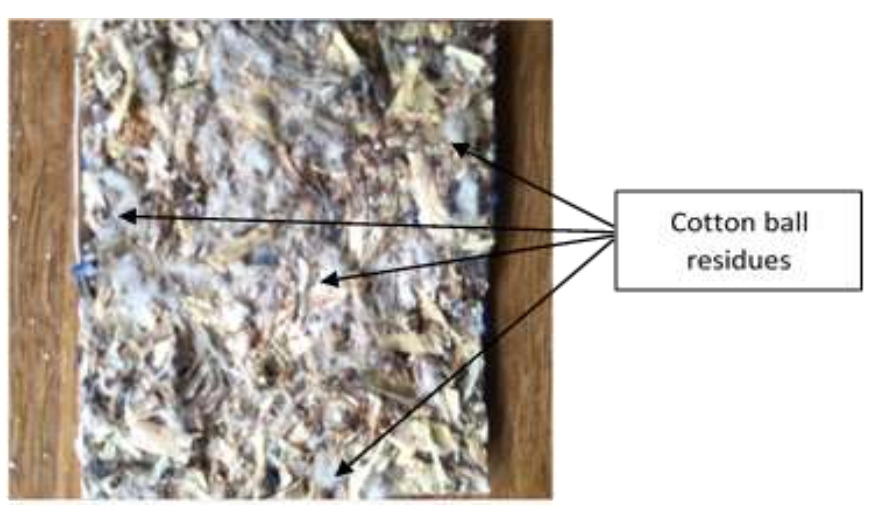

Fig. 8. Distribution of cotton ball residues inside particleboard

The effect of cotton ball residue loading on the internal bond strength is illustrated in Fig. 9. The increase in the content of cotton ball residue resulted in a decreasing IB. The reasons for this decrease are: 1) Poor wettability of cotton balls leading to poor bonding among cotton stalk particles and the cotton ball; and 2) Reduction in the compaction ratio due to cotton ball only existing as single fibers with high density while cotton stalk's density being low. The analysis of variance (Table 14) shows that there was a significant difference in the average value of IB between boards without cotton ball residues and boards with $5 \mathrm{wt} \%, 10 \mathrm{wt} \%$, and $15 \mathrm{wt} \%$ cotton ball residue loading

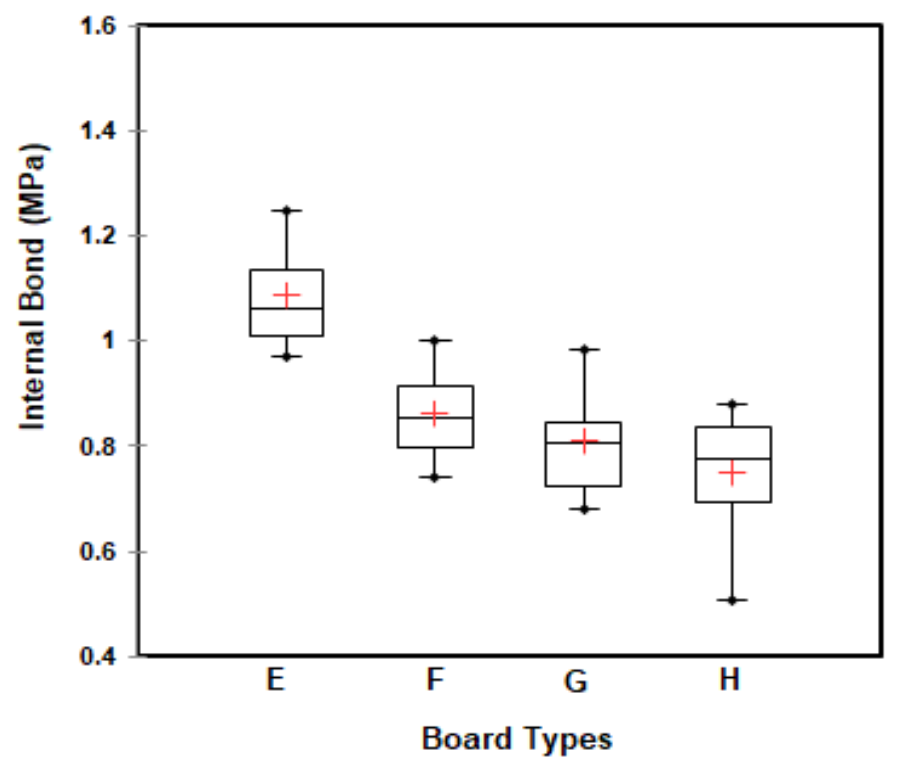

Fig. 9. Effect of cotton ball residue ratios on IB

Table 14. IB ANOVA Multiple Comparison Based on Tukey's Significant Different Test

\begin{tabular}{|c|c|c|c|}
\hline \multirow{2}{*}{ Board Types } & \multirow{2}{*}{$\begin{array}{c}\text { Average of IB } \\
(\mathrm{MPa})\end{array}$} & \multicolumn{2}{|c|}{ Groups Subset for $\alpha=0.05$} \\
\cline { 3 - 4 } & $1.08(0.10)$ & 1 & 2 \\
\hline $\mathrm{E}$ & $0.86(0.09)$ & $\mathrm{x}$ & $\mathrm{x}$ \\
\hline $\mathrm{F}$ & $0.81(0.10)$ & & $\mathrm{x}$ \\
\hline $\mathrm{G}$ & $0.75(0.11)$ & & $\mathrm{x}$ \\
\hline $\mathrm{H}$ & \multicolumn{3}{|c|}{} \\
\hline
\end{tabular}


Figure 10 shows the relationship between cotton ball residue load and thickness swelling after $2 \mathrm{~h}$ and $24 \mathrm{~h}$ of immersion in water, respectively. In general, TS decreased with increasing the percentage of cotton ball residues. The reason for the decrease in thickness swelling with the increasing cotton ball residue load is that hemicelluloses absorb a higher amount of water than cellulose (Sar1 et al. 2014). Cotton ball residue is reported to have only 4\% hemicellulose content (Müssig and Haag 2015), but for cotton stalks the hemicellulose content is approximately 30\% (Ertaş et al. 2010; Tutus et al. 2010; Soulama et al. 2015). The results obtained from the analysis of variance (Table 15) reveal that the decrease in thickness swelling after $2 \mathrm{~h}$ and $24 \mathrm{~h}$ of immersion in water was insignificant. The values reduce from $9.86 \%$ to $9.36 \%$ and from $30.76 \%$ to $26.35 \%$ after $2 \mathrm{~h}$ and $24 \mathrm{~h}$ of immersion in water, respectively.
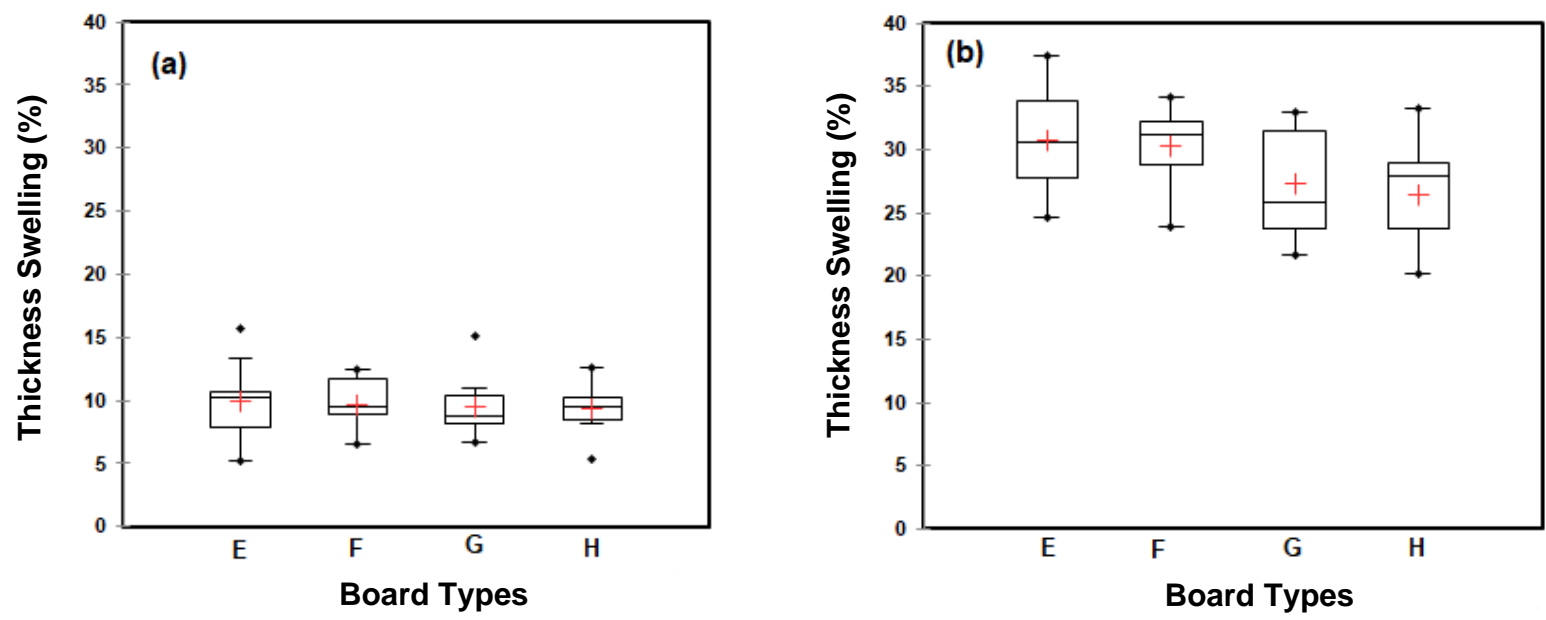

Fig. 10. Effect of cotton ball residue ratios on TS after (a) $2 \mathrm{~h}$ and (b) $24 \mathrm{~h}$

Table 15. TS $2 \mathrm{~h}$ and TS $24 \mathrm{~h}$ ANOVA Multiple Comparison Based on Tukey's Significant Difference Test

\begin{tabular}{|c|c|c|c|c|c|}
\hline \multirow{2}{*}{$\begin{array}{l}\text { Board } \\
\text { Types }\end{array}$} & \multirow{2}{*}{$\begin{array}{c}\text { Average of TS } \\
2 \mathrm{~h} \\
(\%)\end{array}$} & $\begin{array}{l}\text { Groups Subset } \\
\text { for } \alpha=0.05\end{array}$ & \multirow{2}{*}{$\begin{array}{l}\text { Board } \\
\text { Types }\end{array}$} & \multirow{2}{*}{$\begin{array}{c}\text { Average of TS } 24 \\
\mathrm{~h} \\
(\%)\end{array}$} & \multirow{2}{*}{$\begin{array}{c}\text { Groups Subset } \\
\text { for } \alpha=0.05 \\
1\end{array}$} \\
\hline & & 1 & & & \\
\hline$E$ & $9.86(3.20)$ & $x$ & $E$ & $30.76(4.33)$ & $x$ \\
\hline $\mathrm{F}$ & $9.69(1.96)$ & $x$ & $\mathrm{~F}$ & $30.29(3.20)$ & $x$ \\
\hline $\mathrm{G}$ & $9.41(2.57)$ & $x$ & $G$ & $27.31(4.24)$ & $x$ \\
\hline $\mathrm{H}$ & $9.36(2.03)$ & $x$ & $\mathrm{H}$ & $26.35(4.27)$ & $x$ \\
\hline
\end{tabular}

\section{CONCLUSIONS}

This paper presented a thorough investigation of key aspects relevant to the production of particleboard produced from whole cotton stalk agricultural waste. The following key conclusions can be drawn from the research: 
1. Analysis of the resource reveals that only $46 \mathrm{wt} \%$ of the resource is utilized if only cotton stems are used. Consequently, to reduce resource waste the whole cotton stalk should be used.

2. A particle opening size of $8 \mathrm{~mm}$ is the most beneficial for all the particleboard performance properties evaluated including MOR, MOE, IB, and TS. Therefore, a particle opening size of $8 \mathrm{~mm}$ is highly recommended for the core layer for further study on three-layered cotton stalk particleboard.

3. It was clearly established that cotton ball residues have a negative impact on particleboard performance and should be removed.

4. The best performance board type $\mathrm{E}$ (opening particle size of $8 \mathrm{~mm}$ without cotton ball residues) met the minimum requirements of standard particleboard for MOE and IB. However, the MOR (12.4 MPa) of board type E just failed to meet the minimum requirement $(13 \mathrm{MPa})$ of standard particleboard according to the Australian/New Zealand standard AS/NZS 1859.1 (2017).

\section{ACKNOWLEDGMENTS}

The authors acknowledge the Queensland Department of Agriculture and Fisheries for providing materials, technical staff, and access to manufacturing and testing. The first author would also like to thank the Australian Centre for International Agricultural Research (ACIAR) for providing a scholarship for higher education, which was undertaken as a component of the ACIAR Project FST/2016/151 "Advancing enhanced wood manufacturing industries in Laos and Australia."

\section{REFERENCES CITED}

Alma, M. H., Kalaycioğlu, H., Bektaş, I., and Tutus, A. (2005). "Properties of cotton carpel-based particleboards,” Ind. Crop. Prod. 22(2), 141-149. DOI:

10.1016/j.indcrop.2004.08.001

ANSI A208.1 (1999). "Particleboard," American National Standard Institute, Gaithersburg, MD, USA.

AS/NZS 1859.1 (2017) "Reconstituted wood-based panels - Specifications. Part 1:

Particleboard," Australian/New Zealand Standard, Sydney, Australia.

AS/NZS 4266.1 (2017) "Reconstituted wood-based panels - Methods of testing. Part 1:

Base panels," Australian/New Zealand Standard, Sydney, Australia.

Australian Bureau of Agricultural and Resource Economics and Sciences (ABARES) (2017). "Agriculture commodities and trade data," (http://www.agriculture.gov.au/abares/research-topics/agriculturalcommodities/agricultural-commodities-trade-data), Accessed 9 Oct 2017.

Cai, Z., Muehl, J. H., and Winandy, J. E. (2006). "Effects of panel density and mat moisture content on processing medium density fiberboard," Forest Products Journal $56(10), 20-25$.

Dias, F. M., Nascimento, M. F. D., Martinez-Espinosa, M., Lahr, F. A. R., and Valarelli, I. D. D. (2005). "Relation between the compaction rate and physical and mechanical 
properties of particleboards," Mater. Res. 8(3), 329-333. DOI: 10.1590/S151614392005000300018

El-Kassas, A. M., and Mourad, A. H. I. (2013). "Novel fibers preparation technique for manufacturing of rice straw-based fiberboards and their characterization," Mater. Des. 50, 757-765. DOI: 10.1016/j.matdes.2013.03.057

Ertaş, M., Acemioğlu, B., Alma, M. H., and Usta, M. (2010). "Removal of methylene blue from aqueous solution using cotton stalk, cotton waste and cotton dust," $J$. Hazard. Mater. 183(1), 421-427. DOI: 10.1016/j.jhazmat.2010.07.041

FAO (1997). Yearbook of Forest Products 1991-1995, Food and Agriculture Organization of the United Nations, Rome, Italy.

FAO (2002). Yearbook of Forest Products 1996-2000, Food and Agriculture Organization of the United Nations Rome, Italy.

FAO (2007). Yearbook of Forest Products 2001-2005, Food and Agriculture Organization of the United Nations Rome, Italy.

FAO (2009). State of the World's Forests 2009, Food and Agriculture Organization of the United Nations Rome, Italy.

FAO (2012). Yearbook of Forest Products 2006-2010, Food and Agriculture Organization of the United Nations Rome, Italy.

FAO (2017). Yearbook of Forest Products 2010-2015, Food and Agriculture Organization of the United Nations Rome, Italy.

Frazier, C. E. (2003). "Isocyanate wood binders," in: Handbook of Adhesive Technology, 2. DOI:10.1201/9780203912225.ch33

Fu, W. H. (1998). "Raw materials for particleboard," in: Particleboards, China Forestry Publishing House of China, Beijing, China, pp. 10-46.

Gomes, R. S., Wilson, P. N., Coates, W. E., and Fox, R. W. (1997). "Cotton (Gossypium) plant residue for industrial fuel: An economic assessment," Ind. Crop. Prod. 7(1), 18. DOI: 10.1016/S0926-6690(97)00006-X

Guler, C., and Ozen, R. (2004). "Some properties of particleboards made from cotton stalks (Gossypium hirsutum L.)," Holz. Roh. Werkst. 62(1), 40-43. DOI: 10.1007/s00107-003-0439-9

He, G., and Yan, N. (2005). "Effect of moisture content on curing kinetics of pMDI resin and wood mixtures," International Journal of Adhesion and Adhesives 25(5), 450455. DOI: 10.1016/j.ijadhadh.2004.12.002

Kadja, K., Banna, M., Atcholi, K. E., and Sanda, K. (2011). "Utilization of bone adhesive to produce particleboards from stems of cotton plant at the pressing temperature of $140{ }^{\circ}$ C," Am. J. Appl. Sci. 8(4), 318-322. DOI: 10.3844/ajassp.2011.318.322

Kargarfard, A., and Latibari, A. J. (2011). "The performance of corn and cotton stalks for medium density fiberboard production," BioResources 6(2), 1147-1157. DOI: 10.15376/biores.6.2.1147-1157

Khanjanzadeh, H., Bahmani, A., Rafighi, A., and Tabarsa, T. (2012). "Utilization of biowaste cotton (Gossypium hirsutum L.) stalks and underutilized paulownia (Paulownia fortunei) in wood-based composite particleboard," Afr. J. Biotechnol. 11(31), 80458050. DOI: 10.5897/AJB12.288

Kusumah, S. S., Umemura, K., Yoshioka, K., Miyafuji, H., and Kanayama, K. (2016). "Utilization of sweet sorghum bagasse and citric acid for manufacturing of particleboard I: Effects of pre-drying treatment and citric acid content on the board properties," Ind. Crop. Prod. 84, 34-42. DOI: 10.1016/j.indcrop.2016.01.042 
Li, L., Sun, J., and Jia, G. (2012). "Properties of natural cotton stalk bark fiber under alkali treating," J. Appl. Polym. Sci. 125(S2), E534-E539. DOI: 10.1002/app.36987

Müssig, J., and Haag, K. (2015). "The use of flax fibres as reinforcements in composites," in: Biofiber Reinforcement in Composite Materials, O. Faruk and M. Sain (eds.), Woodhead Publishing, Cambridge, United Kingdom, pp. 35-82.

Nazerian, M., Beygi, Z., Mohebbi Gargari, R., and Kool, F. (2018). "Application of response surface methodology for evaluating particleboard properties made from cotton stalk particles," Wood Mater. Sci. Eng. 13(2), 73-80. DOI: 10.1080/17480272.2017.1307280

Nazerian, M., Beyki, Z., Gargarii, R. M., and Kool, F. (2015). "The effect of some technological production variables on mechanical and physical properties of particleboard manufactured from cotton (Gossypium hirsutum) stalks," MaderasCienc. Tecnol. 18(1), 167-178. DOI: 10.4067/S0718-221X2016005000017

Pirayesh, H., and Khazaeian, A. (2012). "Using almond (Prunus amygdalus L.) shell as a bio-waste resource in wood-based composite," Compos. Part B-Eng. 43(3), 14751479. DOI: 10.1016/j.compositesb.2011.06.008

Sarı, B., Ayrilmis, N., Nemli, G., Baharoğlu, M., Gümüşkaya, E., and Bardak, S. (2014). "Effect of chemical composition of wood and resin type on properties of particleboard," Lignocellulose Journal 1(3), 174-184.

Seedahmed, A. I. (2014). "Cotton stalks fiber-reinforced polypropylene composites: Comparison of experimental data and calculated tensile strength and elastic modulus," Int. J. Eng. Sci. 3(3), 108-115.

Soulama, S., Atcholi, K. E., Naon, B., Kadja, K., and Sanda, K. (2015). “Optimization of the implementation process and physical properties of cotton (Gossypium hirsutum) and Kenaf (Hibiscus cannabinus L.) wooden chipboard," Engineering-London 7(12), 803-815. DOI: 10.4236/eng.2015.712070

TS-EN 312-2 (1999). "Particleboards - Specifications - Part 2: Requirements for general purpose boards for use in dry condition," Turkish Standards Institution, Ankara, Turkey.

Tutus, A., Ezici, A. C., and Ates, S. (2010). "Chemical, morphological and anatomical properties and evaluation of cotton stalks (Gossypium hirsutum L.) in pulp industry," Sci. Res. Essays 5(12), 1553-1560.

Zhou, X.-Y., Zheng, F., Li, H.-G., and Lu, C.-L. (2010). "An environment-friendly thermal insulation material from cotton stalk fibers," Energ. Buildings 42(7), 10701074. DOI: 10.1016/j.enbuild.2010.01.020

Article submitted: June 8, 2020; Peer review completed: August 3, 2020; Revised version received and accepted: August 19, 2020; Published: August 25, 2020.

DOI: $10.15376 /$ biores.15.4.7730-7748 